\title{
Heavy Metal Contributions on Human Skin Disease near Cement Plant: A Systematic Review
}

\author{
Annisa Utami Rauf*, Anwar Mallongi, Ratna Dwi Puji Astuti \\ Department of Environmental Health, Faculty of Public Health, Hasanuddin University, Indonesia
}

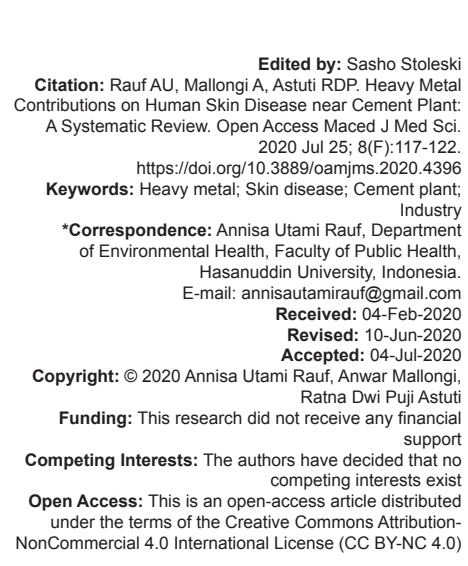

\section{Introduction}

Heavy metals have a long half-life and found in the body through the skin, food, or drink [1]. Heavy metal released from industrial activity, coal combustion, and mining. Moreover, if heavy metal particulates are carried by the wind, the distribution is able to reach a far place from the source while the wind blows. Heavy metal is one of the most serious environmental pollutants because of its toxicity, abundant, easily accumulated by various plants and organisms [2]. Exposure to heavy metal are associated with cancer [3], [4], obesity [5], infant mortality [6], cognitive problem, and skin damage [7].

Industries have been considered as a source of heavy metal. The main problem that some industries, and more specifically, cement industries, still have to deal with is the requirement to determine and control the content of some chromium, nickel, and cobalt compounds due to their allergenic effects on human health [8]. Some important studies mentioned the harmful effects of $\mathrm{Cr}(\mathrm{VI})$ on human health, mainly skin in contact with cement such as dermatitis [7], [9]. Dermatitis is an inflammatory skin condition which will be found around the cement industry area with symptoms of itching, redness, burning, and skin irritation from the contact of cement corrosive components. Furthermore, increasing heavy metal concentration near the plant related with extreme skin disease, for example, skin cancer and mortality from cement manufacturing activities [10].

Skin damage of cement industrial can be caused through physical insults, biologic cause, and long-high concentration of chemical exposure [11]. For workers, occupational exposure to heavy metal occurs mainly through inhalation and dermal absorptions in the working environment. Similarly, residence in near of an industrial activities affected by the toxicity of excess material from factory for many years [12]. The skin can be one of the most vulnerable organs of heavy metals penetration into human body surfaces. Disorders and signs of the skin disease occur in a short and long time period depending on the concentration, heavy metal characteristics, and duration of exposure. Redness was an initial symptom that a human skin sign and being a possible alert of a skin problem. However, legislative initiatives may be necessary to protect all humans near to cement industrial area for a threshold level concern and protective plan [13]. 


\section{Materials and Methods}

\section{Eligibility criteria}

The criteria were determined based on the format $(\mathrm{P}=$ Population, $\mathrm{I}=$ Intervention, $\mathrm{C}=$ Comparison, $\mathrm{O}=$ Outcome, and $\mathrm{S}=$ Study Design).

$P=$ Patients at any age, sex, and activity indicates skin disease near the cement plant

I = Heavy metal exposure and induced to skin

$\mathrm{C}=$ No exposure; occupational risk; concentration

$\mathrm{O}=$ Heavy metal contributions and roles on skin disease

$\mathrm{S}=$ Observational studies

\section{Search strategy}

This literature review assessed and arranged using the 2015 preferred reporting items for systematic reviews and meta-analysis (PRISMA) guidelines. List of relevant words was selected and determined to get peerview articles on an appropriate topic. A computerized literature searches in four international online databases: DOAJ, PubMed, SpringerLink, and Google Scholar. All published papers and reports associated with the subject of this study from January-2009 to December-2019. We performed a systematic search using Mesh terms including: "Heavy metal exposures," "dermatitis," "cement industry," "mercury," "lead," "arsenic," "chromium," "hexavalent chromium," "skin lesions," and "skin cancer." The "AND" and "OR" operators were used. The combination of keywords used in this research was (dermatitis) OR (skin cancer) OR (eczema) AND (heavy metal) AND (industry) OR (cement) AND (chromium).

\section{Inclusion and exclusion criteria}

Articles taken from each database are imported into the Mendeley Library. For additional relevant publications that might be missed, we look for bibliographic references from all articles that met the inclusion criteria. The research inclusion criteria, focusing on cement plant area (residences, workers, and patients); an observational study; heavy metal exposure to skin; published in 2009-2019; English articles; and peer view journal. We excluded studies for following reasons; if the data contain less information in methods, no original data included qualitative studies, nonepidemiological research, articles published in predatory publication, small amount of sample $(<50)$, unmentioned locations, and industrial health effect to skin except cement industry. Three reviewers extracted the results and read all the unique papers and assess them with exclusion and inclusion criteria. The titles and abstracts of papers were read, and all papers were unrelated to research objective (heavy metal related to skin disease) were excluded from further analysis (189 papers).

\section{Data extraction and quality assessment}

Data on the following characteristic were screened by reviewers using eight indicators of qualityappraisal criteria derived from Strengthening the Reporting of Observational Studies in Epidemiology (STROBE) checklist. The checklist consists of 22 items that are used to evaluate external validity (based on potential selection bias) and internal validity (based on the potential measurement and confounding bias) from observational studies. After the initial assessment of all studies reviewed based on 22 STROBE items, these items then grouped into eight quality assessment criteria (sample size, sampling methodology, response rate, outcome measures, statistical analyses, control for confounding, study limitation, and ethical consideration). STROBE checklist $(0-8)$ becomes the standard criteria for selecting articles. Studies that scored $<3$ considered to be low quality, 3-6 medium, and 7-8 as a good quality study. Articles rate with $<7$ will be removed and if they gained a good rate (7-8), they would be taken. Fourteen studies were selected based on the quality criteria. There were five studies with a rate of 8 and 9 studies with a rate of 7 . The diagram of paper selection is shown in Figure 1.

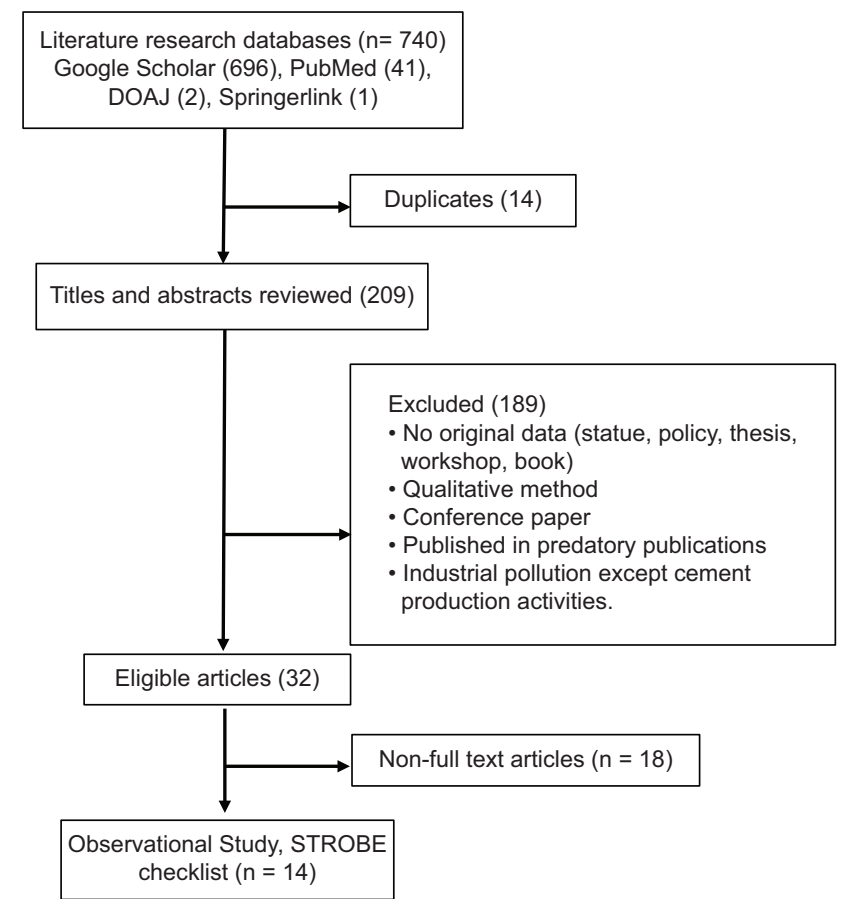

Figure 1: Preferred reporting items for systematic reviews and metaanalyses flow diagram of paper selection

\section{Results}

\section{Skin disease}

Exposure of heavy metals from coal combustion and high-temperature processes in the industry will release harmful particles (gas, dust, and metals) [14]. Cement dust has a significant correlation with health 
outcomes. Minor health problems such as coughing [15], itching, and red eyes are mild symptoms that will arise due to body response to environmental quality. The industry is the sector that associated with population health problems. Dust from industries accumulates and frequently gets in contact with skin constantly through hands and forearms [16]. Alkalinity and corrosive materials in cement show effect and allergic to skin. Small outdoor jobs gained the highest number of dermatitis than other divisions in cement factories that usually done mechanically, especially indoor jobs. The less contact to skin, the fewer cases will appear.

In the cement industry, workers face the danger of routine exposure from allergens in their work. One of the most susceptible damage organs in humans is skin. Therefore, protection gloves that cover the surface of the skin are crucial. Dust in the cement industry is different from the dust around the roadside. The dust in cement contains silica [17], [18] and heavy metals [19]. Long term exposure affected the epidermal skin layer, protein metabolism, and DNA damage [10]. Dermatitis is a skin disease that is always found in workers in the cement industry, where most chromium, nickel, and cobalt will be found [20]. Irritant and allergic contact dermatitis are considered the most frequent occupational health hazards in cement workers.

\section{Metal sensitivity}

Exposure to heavy metals has been extensively studied and reported as evidence for disorders of human skin in the vicinity of the cement industry. Dermatitis is a disease from external exposure from allergens, for example, chemicals [21]. If it is no further contact from an allergens, the redness, crusts, and itching will disappear. Common sources of exposure to the skin are tanned leather and cement. Dermatitis resulting from exposure to $\mathrm{Cr}(\mathrm{VI})$ can occur either by direct dermal contact or by ingestion [22]. Chromium found on the skin of patients with dermatitis proven by a skin patch test. Metals that cause systemic contact dermatitis are aluminum, chromium, cobalt, copper, gold, mercury, nickel, and zinc [23]. The safest limit of chromium exposure in the cement industry is $1 \mathrm{mg} / \mathrm{Nm} 3$ [24]. Chromium, in hexavalent form, is both toxic and carcinogenic. A Cr (IV) allergic patients also give a positive reaction to cobalt in a workplace. Based on Table 1, this theory related

Table 1: Skin disease reporting due to heavy metal

\begin{tabular}{|c|c|c|c|c|c|c|}
\hline Author/year & Study design & $\begin{array}{c}\text { Quality of } \\
\text { assessment }\end{array}$ & $\begin{array}{l}\text { Study group ( } \mathrm{N} \text { of subject, } \\
\text { variables/risk factor) }\end{array}$ & Prevalence of skin disease & $\begin{array}{l}\text { Diagnosis of skin disease } \\
\text { (observed symptoms; analysis } \\
\text { method) }\end{array}$ & Location/Site \\
\hline $\begin{array}{l}\text { Lejding et al. } \\
\text { (2018) }\end{array}$ & $\begin{array}{l}\text { Case control } \\
\text { study }\end{array}$ & 7 & $\begin{array}{l}6482 \text { patients (construction } \\
\text { activities); leisure activities and } \\
\text { occupational cement contact; } \\
\text { age }\end{array}$ & $\begin{array}{l}157 \mathrm{Cr}(\mathrm{IV}) \text { and Cobalt-Allergic female and } \\
76 \mathrm{Cr}(\mathrm{IV}) \text { and Cobalt Allergic male related } \\
\text { to dermatitis }\end{array}$ & $\begin{array}{l}\text { Eczema, allergic contact to } \\
\text { dermatitis; Skin patch test }\end{array}$ & Southern Sweden \\
\hline $\begin{array}{l}\text { Cha et al. } \\
(2011)\end{array}$ & $\begin{array}{l}\text { Case control } \\
\text { study }\end{array}$ & 7 & $\begin{array}{l}374 \text { respondents; age, drinking } \\
\text { alcohol, urinary level of } \mathrm{Cr}\end{array}$ & $\begin{array}{l}17 \text { in Sinpyeong, } 44 \text { in SsangYong, } 28 \text { in } \\
\text { Ipseok and } 13 \text { in Kwangkyeong (control). } \\
\text { Chromium and mercury high concentration } \\
\text { in exposure group of dermatitis disease }\end{array}$ & $\begin{array}{l}\text { Burns sensitization and skin } \\
\text { ulcer; Urinary analysis }\end{array}$ & $\begin{array}{l}\text { Yeongwol, } \\
\text { Jaecheon, and } \\
\text { Wonju City, South } \\
\text { Korea }\end{array}$ \\
\hline $\begin{array}{l}\text { Koh et al. } \\
(2011)\end{array}$ & Cohort study & 7 & $\begin{array}{l}5596 \text { respondents (cement } \\
\text { workers); age, sex }\end{array}$ & 1 observed case for skin cancer & $\mathrm{n} / \mathrm{a}$ & $\begin{array}{l}6 \text { Portland cement } \\
\text { factories in South } \\
\text { Korea }\end{array}$ \\
\hline $\begin{array}{l}\text { Perez et al. } \\
(2015)\end{array}$ & $\begin{array}{l}\text { Ecological } \\
\text { study }\end{array}$ & 7 & $\begin{array}{l}36667 \text { observed death by cancer } \\
\text { (cement workers); specific rate } \\
\text { by age group }\end{array}$ & $\begin{array}{l}25 \text { observed death related to skin cancer } \\
\text { (14 men, } 11 \text { women) }\end{array}$ & $\mathrm{n} / \mathrm{a}$ & Spain \\
\hline $\begin{array}{l}\text { Kridin et al. } \\
(2016)\end{array}$ & Cohort study & 8 & $\begin{array}{l}4846 \text { patients (cement workers); } \\
\text { sex, occupational allergic to } \\
\text { cement and age }\end{array}$ & $\begin{array}{l}146 \text { positive for potassium chromate, } 46 \\
\text { chromate allergic patients OACD, } 27 / 46 \text { had } \\
\text { cement induced chromate OACD }\end{array}$ & $\begin{array}{l}\text { Metal allergy (Cobalt, Nickel, } \\
\text { Chromate); Skin patch test }\end{array}$ & Israel \\
\hline $\begin{array}{l}\text { Afridi et al. } \\
\text { (2010) }\end{array}$ & $\begin{array}{l}\text { Case- } \\
\text { control study }\end{array}$ & 8 & $\begin{array}{l}241 \text { respondents (live in town } \\
\text { since birth and were } \\
25-55 \text { years old) }\end{array}$ & $\begin{array}{l}\text { Increasing } \mathrm{Cd}, \mathrm{Cr} \text { and } \mathrm{Ni} \text { concentrations } \\
\text { made } 124 \text { exposed to Psoriasis, } 63 \text { male } \\
\text { and } 61 \text { female }\end{array}$ & $\begin{array}{l}\text { n/a; Biological sample (scalp } \\
\text { hair, blood, and urine) }\end{array}$ & Hyderabad, Pakistan \\
\hline $\begin{array}{l}\text { Elhosary } \\
\text { et al. (2014) }\end{array}$ & $\begin{array}{l}\text { Case- } \\
\text { control study }\end{array}$ & 7 & $\begin{array}{l}65 \text { males ( } 14-65 \text { years); coffee/ } \\
\text { tea drinking, smoking, residence, } \\
\text { education }\end{array}$ & $\begin{array}{l}\text { Cr levels of two exposure group were } \\
\text { higher, about }(22.7 \%) \text { of cement and } \\
(35 \%) \text { of tannery workers had severe skin } \\
\text { manifestations. ; n/a }\end{array}$ & $\begin{array}{l}\text { fissured skin and chrome } \\
\text { ulcers; Laboratory investigation } \\
\text { were carried out by blood and } \\
\text { urine sample }\end{array}$ & Egypt \\
\hline $\begin{array}{l}\text { Thomas et al. } \\
\text { (2015) }\end{array}$ & $\begin{array}{l}\text { Case- } \\
\text { control study }\end{array}$ & 8 & 250 respondents; n/a & $\begin{array}{l}49 \text { of } 250 \text { patients reacted to one or more } \\
\text { bone cement constituents, } 2 \text { patients in } \\
\text { potassium dichromate, } 1 \text { patient in cobalt } \\
\text { chloride, } 11 \text { to nickel sulfate }\end{array}$ & $\begin{array}{l}\text { Pain, recurrent effusions, } \\
\text { reduced range of motion, } \\
\text { eczema or loosening; skin } \\
\text { patch test }\end{array}$ & Germany \\
\hline $\begin{array}{l}\text { Wong et al. } \\
(2014)\end{array}$ & $\begin{array}{l}\text { Case control } \\
\text { study }\end{array}$ & 8 & 3685 respondents; n/a & $\begin{array}{l}47(41 \%) \text { cases of chromium OACD caused } \\
\text { by cement were identified }\end{array}$ & $\begin{array}{l}\text { Allergic reaction; skin patch } \\
\text { test }\end{array}$ & Australia \\
\hline $\begin{array}{l}\text { Schwensen } \\
\text { et al. (2014) }\end{array}$ & $\begin{array}{l}\text { Case- } \\
\text { control study }\end{array}$ & 7 & $\begin{array}{l}1471 \text { blue-collar workers, DISCO } \\
88 ; \text { MOALHFA index, sex, age }\end{array}$ & $\begin{array}{l}64 \text { over } 1468 \text { had positive allergy to } \\
\text { potassium chromate, } 68 \text { were allergic to } \\
\text { cobalt chloride, } 178 \text { were allergic to nickel } \\
\text { sulfate }\end{array}$ & $\begin{array}{l}\text { contact allergy, sensitization; } \\
\text { Skin patch test }\end{array}$ & Denmark \\
\hline $\begin{array}{l}\text { Thyssen et al. } \\
\text { (2010) }\end{array}$ & $\begin{array}{l}\text { Case- } \\
\text { control study }\end{array}$ & 8 & $\begin{array}{l}22506 \text { patients with dermatitis; } \\
\text { MOAHLFA index, sex }\end{array}$ & $\begin{array}{l}1281 \text { nickel allergic patients, } 425 \text { cobalt } \\
\text { allergic patients, } 275 \text { chromate allergic } \\
\text { patients }\end{array}$ & $\begin{array}{l}\text { redness, infiltration, irritant } \\
\text { response; skin patch test }\end{array}$ & Denmark \\
\hline $\begin{array}{l}\text { Le et al. } \\
(2010)\end{array}$ & $\begin{array}{l}\text { Case- } \\
\text { control study }\end{array}$ & 7 & $\begin{array}{l}110 \text { patients with eczema and } 41 \\
\text { patients with miscellaneous skin } \\
\text { conditions (SCORAD, NESS); } \\
\text { age, sex, dietary intake }\end{array}$ & $\begin{array}{l}44 \text { patients with eczema and } 24 \text { in non- } \\
\text { eczema had a low level of copper }\end{array}$ & $\begin{array}{l}\mathrm{n} / \mathrm{a} \text {; Serum level by pediatric } \\
\text { dermatology clinic }\end{array}$ & Hong Kong \\
\hline $\begin{array}{l}\text { Thyssen et al. } \\
\text { (2009) }\end{array}$ & $\begin{array}{l}\text { Case- } \\
\text { control study }\end{array}$ & 7 & $\begin{array}{l}16228 \text { patients, MOAHLFA } \\
\text { index; age, test year, sex }\end{array}$ & $\begin{array}{l}100 \text { patients had positive test reaction to } \\
\text { chromium }\end{array}$ & $\begin{array}{l}\text { Chromium allergy to skin; skin } \\
\text { patch test }\end{array}$ & Denmark \\
\hline $\begin{array}{l}\text { Wang et al. } \\
\text { (2011) }\end{array}$ & $\begin{array}{l}\text { Cross- } \\
\text { sectional } \\
\text { study }\end{array}$ & 7 & 97 cement workers; sex & $\begin{array}{l}24 \text { males were allergic to potassium } \\
\text { chromate, } 4 \text { males were allergic to nickel } \\
\text { sulfate }\end{array}$ & $\begin{array}{l}\text { Thickened, hyperkeratosis, } \\
\text { scaling, dryness, erythema, } \\
\text { fissure, pigmentation, scratch, } \\
\text { ulceration, erosion, edema, } \\
\text { itching, vesicles; Skin patch test }\end{array}$ & Tainan City, Taiwan \\
\hline
\end{tabular}


to Lejding (2018), Schwensen (2014), Thomas (2015), and Thyssen (2010) research. Chromium in cement to $<2 \mathrm{ppm}$ through the addition of ferrous sulfate to cement has seen a significant decrease in the incidence of chromium allergy [25]. It means, reducing and controlling chromium in the cement industry are required.

Nickel allergy is the most common cause of Allergic Contact Dermatitis (ACD), and its incidence is thought to be increasing by the growth of industries. Sensitized individuals who are exposed to nickel on their skin or mucosal surfaces generally have a predictable localized response, including erythema, vesicles, scaling, and pruritus [23]. Furthermore, the cement factory in the USA has been lead to human skin disease and cobalt exposure recorded about $0.02-0.5$ ppm in different countries [26]. Cobalt allergy may also occur in the construction industry, primarily through skin contact with cement.

Mercury, one of the most toxic heavy metals also found in serum samples of skin chronic disease detection. Body burden of mercury associated with eczema [27]. Raw materials in cement contain mercury, lead, cadmium from fuel, and coal [28]. These heavy metals determined by metallothionein analysis in serum, hair, and nail as a biomarker for metal detection. In Table 1, Afridi (2010) found a high concentration of $\mathrm{Cd}, \mathrm{Cr}$, and $\mathrm{Ni}$ and the high number of psoriasis in males and females in Pakistan. Psoriasis is a chronic skin condition, unnoticeable, and long-lasting. These carcinogenic elements can trigger skin disease.

MOAHLFA(Male, Occupation, Atopic dermatitis, Hand eczema, Leg dermatitis, Facial dermatitis, and Age > 40 years) index used by Schwensen (2014) and Thyssen (2010) to determine associations characteristics of patients of allergic contact dermatitis [34]. Skin patch tests commonly used for all patients with Atopic Dermatitis [35]. Homogeneous redness and infiltration in the entire test area were scored as a $1+$ reaction. Homogeneous redness, infiltration, and vesicles in the test area were scored as a 2+ reaction and homogeneous redness, infiltration, and coalescing vesicles in the test area as a $3+$ reaction. A 1+, 2+, or $3+$ reading was interpreted as a positive response. An irritant response, a doubtful (+?), or a negative reading was interpreted as a negative response [36].

\section{Risk factors}

The working area is a crucial and determining factor in the emergence of skin disease. Human activities will affect the health outcome and illness. In the cement industry, workers in the industry are the riskiest population for skin diseases due to allergen induction. The most common skin disease related to heavy metal in cement was dermatitis. Lejding (2018) investigated 6482 patients working in the construction and cement sectors in Sweden, 157 women and 76 men were associated with heavy metal chromium and cobalt exposure. Chromium and cobalt were also found on the skin of workers in Tainan City, Taiwan with 23 men and one woman allergic to potassium chromate, four women allergic to nickel sulfate over 97 cement workers [29].

Research in Denmark found that 64 over 1468 blue-collar workers had a positive allergy to potassium chromate, 68 to cobalt chloride and 178 were allergic to nickel sulfate [30]. Kridin (2016) reported 46 chromate allergic patients of occupational allergic contact dermatitis from 4846 cement workers in Israel and increase currently. In terms of skin cancer, mortality recorded in two countries. One case of skin cancer of cement producing workers revealed in South Korea. This case happened to a worker who had been worked for 30 years. Furthermore, In Spain, an ecological study caused 14 cancer incidence in male and 11 female cement workers. All of the patients with skin cancer worked in a cement plant [31].

Residence or non-workers in the cement industry face a huge problem. In the study of heavy metal exposure of $\mathrm{Cd}, \mathrm{Cr}, \mathrm{Ni}$, and $\mathrm{Zn}$ in biological samples of psoriasis for living human near cement in Pakistan, the result was significantly higher for residence than control. Moreover, other diseases experienced by residents living next to the cement plant were eczema and dermatitis. Topsoil heavy metal able to mobilize based on the wind direction and dissolved in consumed water [32]. Patients with skin diseases took a higher heavy metal concentration than the control/ un-exposure group in their skin surface and biological samples (hair, blood, and nails), and it accumulates for a long period. It was found that chromium levels in blood and urine from cement workers were higher than control in Egypt [33].

Table 2: Prevalence of skin disease from cement industry in 2009 to 2019

\begin{tabular}{|c|c|c|c|c|c|}
\hline Author & Total sample & Skin disease cases & Amount of cases (\%) & Heavy metal & Observation study \\
\hline Lejding et al. (2018) & 6482 & 233 & 3.59 & $\mathrm{Cr}(\mathrm{IV})$ & 10 years \\
\hline Cha et al. (2011) & 374 & 102 & 27.27 & $\mathrm{Cr}$ (IV), $\mathrm{Hg}, \mathrm{Cd}, \mathrm{Pb}$ & $n / a$ \\
\hline Koh et al. (2011) & 5596 & 1 & 0.02 & $\mathrm{Cr}(\mathrm{VI})$ & 8,15 years \\
\hline Perez et al. (2015) & 36667 & 25 & 0.07 & $\mathrm{Cr}(\mathrm{IV}), \mathrm{Mg}$ & 9 years \\
\hline Kridin et al. (2016) & 4846 & 146 & 3.01 & $\mathrm{Cr}(\mathrm{VI})$ & 14 years \\
\hline Afridi et al. (2010) & 241 & 124 & 51.45 & $\mathrm{Cr}$ (III), $\mathrm{Cr}$ (IV), $\mathrm{Cr}$ (VI), Ni, Cd & $\mathrm{n} / \mathrm{a}$ \\
\hline Elhosary et al. (2014) & 65 & 27 & 41.54 & $\mathrm{Cr}(\mathrm{IV})$ & 1 year \\
\hline Thomas et al. (2015) & 250 & 49 & 19.60 & $\mathrm{Cr}(\mathrm{IV})$ & 3 years \\
\hline Wong et al. (2014) & 3685 & 47 & 1.28 & $\mathrm{Cr}(\mathrm{IV})$ & 20 years \\
\hline Schwensen et al. (2014) & 1471 & 310 & 21.07 & $\mathrm{Cr}(\mathrm{IV})$ & 9 years \\
\hline Thyssen et al. (2010) & 22506 & 1981 & 8.80 & $\mathrm{Cr}(\mathrm{VI}), \mathrm{Ni}, \mathrm{Co}$ & 33 years \\
\hline Le et al. (2010) & 151 & 68 & 45.03 & $\mathrm{Zn}, \mathrm{Cu}$ & 1 year \\
\hline Thyssen et al. (2009) & 16228 & 7 & 0.04 & $\mathrm{Cr}$ (III), $\mathrm{Cr}$ (IV) & 22 years \\
\hline Wang et al. (2011) & 97 & 28 & 28.87 & $\mathrm{Cr}(\mathrm{VI})$ & $n / a$ \\
\hline Total & 98659 & 3148 & & & \\
\hline
\end{tabular}

Total 
The prevalence of skin diseases caused by heavy metals described that the amount of case-control studies was greater than others (Table 1) and being the most common methods $(n=10)$. The complete data from all reviewed papers of prevalence of skin disease in 2009-2019 are described in Table 2 and Figure 2. There was 98659 samples from 10 years studies and 3148 cases had positive tested to heavy metal and indicated as skin disease.

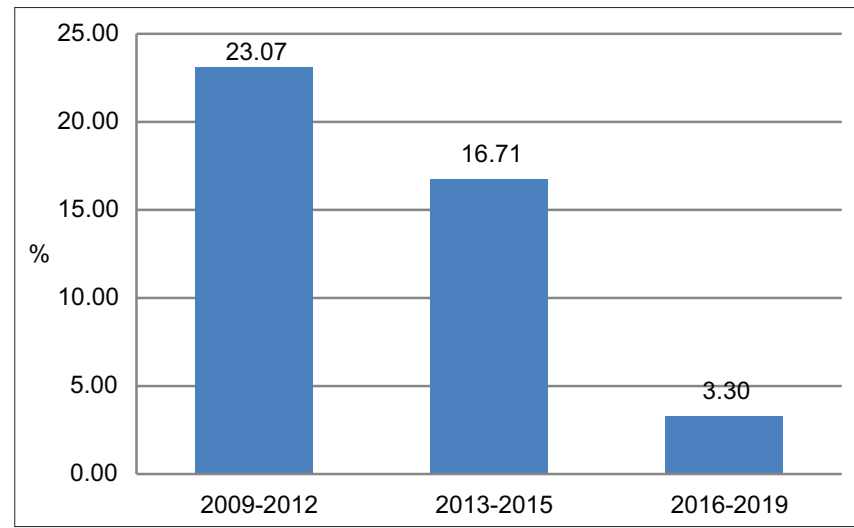

Figure 2: The columns represent 3 years period (e.g., 2009-2012, we could assume that the last column was 3 years because no research found in 2019) and proportions of patients who tested positive for skin disease due to heavy metal exposure near the cement plant

\section{Strengths and limitations}

Long-term consequences of human exposure to cement dust should be investigated. The number of papers and the specific risk factors was not significantly mapping the issues. Skin disease association with heavy metal in the cement area is less than lung inflammations, cardiovascular, and cancer studies. Therefore, we observed a positive association between chromium-cobalt allergies with dermatitis. For specific elements such as mercury and cadmium, the exposure may be classified as a chronic level. These two elements accumulated in the organism body and made an important role in environmental biomonitoring but did not explain the process to lead skin cancer.

A total 14 studies shown a diverse location (Sweden=1, South Korea=2, Spain=1, Israel=1, Pakistan=1, Egypt=1, Germany=1, Australia=1, Denmark=3, Hong Kong=1, and Taiwan=1). Our review was collect various methods and recent data in skin disease focusing on the cement industry. Some studies did not mention the specific symptoms relates to skin cancer but obtained good data for mortality rate. Only the age and occupation variables showed high relevance with the incidence of skin disease, in contrast to gender variables, which produced different results for each study - heavy metal exposure to a human living in a cement industrial area associated with the number of skin disease. The result of this systematic review mentioned chromium, nickel, and cobalt was a major element appearing on skin patch test and other tests. Elements such as cadmium, lead, and mercury usually are found in chronic skin disease on a biologic test. These findings should raise an important concern and recommendation policy for controlling heavy metal in industrial area for worker and non-worker. Further detailed work and research, however, to better characterize these associations, risk factors, and to assess causality, are needed.

\section{Conclusion}

Heavy metal exposure to a human living in a cement industrial area is associated with the case of skin disease. The result of this systematic review mentioned chromium, nickel, and cobalt was a major element appearing on skin patch test and other tests. Signs and mild symptoms of skin disease include redness, itching, starch, and dryness. Elements such as cadmium, lead, and mercury usually are found in chronic skin disease on a biologic test. These findings should raise an important concern and recommendation policy for controlling heavy metal in industrial area for worker and non-worker. Further detailed work and research, however, to better characterize these associations, risk factors, and to assess causality are needed.

\section{References}

1. Amer MM, Sabry BA, Marrez DA, Hathout AS, Fouzy AS Exposure assessment of heavy metal residues in some Egyptian fruits. Toxicol Rep. 2019;6:538-43. https://doi.org/10.1016/j. toxrep.2019.06.007

2. ACGIH. Threshold Limit Values for Chemical Substances and Physical Agents and Biological Exposure Indices. Cincinnati: ACGIH Worldwide, Signature Publications; 2004. p. 109-28.

3. Bai L, Wang Y, Guo Y, Zhou Y, Xie X. Health risk assessment research on heavy metals ingestion through groundwater drinking pathway for the residents in Baotou, China. J Environ Health. 2016;78(6):84-91.

PMid:26867296

4. Taner S, Pekey B, Pekey H. Fine particulate matter in the indoor air of barbeque restaurants: Elemental compositions, sources and health risks. Sci Total Environ. 2013;454-455:79-87. https:// doi.org/10.1016/j.scitotenv.2013.03.018 PMid:23542481

5. Wang X, Mukherjee B, Park SK. Associations of cumulative exposure to heavy metal mixtures with obesity and its comorbidities among U.S. adults in NHANES 2003-2014. Environ Int. 2018;121:683-94. https://doi.org/10.1016/j. envint.2018.09.035

PMid:30316184

6. Geng HX, Wang L. Cadmium: Toxic effects on placenta and embryonic development. Environ Toxicol Pharmacol. 2019;67:102-7.

PMid:30797179

7. Chou TC, Wang PC, Wu J De, Sheu SC. Chromiuminduced skin damage among Taiwanese cement workers. 
Toxicol Ind Health. 2016;32(10):1745-51. https://doi. org/10.1177/0748233715584699

PMid:25964241

8. Frías M, De Rojas MI. Total and soluble chromium, nickel and cobalt content in the main materials used in the manufacturing of Spanish commercial cements. Cem Concr Res. 2002;32(3):43540. https://doi.org/10.1016/s0008-8846(01)00701-3

9. Afridi HI, Kazi TG, Kazi N, Kandhro GA, Baig JA, Shah AQ, et al. Evaluation of cadmium, chromium, nickel, and zinc in biological samples of psoriasis patients living in Pakistani cement factory area. Biol Trace Elem Res. 2011;142(3):284-301. https://doi. org/10.1007/s12011-010-8778-y PMid:20665125

10. Koh DH, Kim TW, Jang SH, Ryu HW. Cancer mortality and incidence in cement industry workers in Korea. Saf Health Work. 2011;2(3):243-9. https://doi.org/10.5491/shaw.2011.2.3.243 PMid:22953208

11. Lushniak BD. Occupational contact dermatitis. Dermatol Ther. 2004;17(3):272-7.

PMid:15186373

12. Cha KT, Oh SS, Yoon JH, Lee KH, Kim SK, Cha BS, et al. Adverse health outcomes in residents exposed to cement dust. Toxicol Environ Health Sci. 2011;3(4):239-44. https://doi. org/10.1007/s13530-011-0101-6

13. Thyssen JP, Jensen $P$, Carlsen BC, Engkilde K, Menné T, Johansen JD. The prevalence of chromium allergy in Denmark is currently increasing as a result of leather exposure. Br J Dermatol. 2009;161(6):1288-93. https://doi. org/10.1111/j.1365-2133.2009.09405.x

\section{PMid:19673874}

14. Sigvardsen NM, Ottosen LM. Characterization of coal bio ash from wood pellets and low-alkali coal fly ash and use as partial cement replacement in mortar. Cem Concr Compos. 2019;95:2532. https://doi.org/10.1016/j.cemconcomp.2018.10.005

15. Aljeesh Y, Al Madhoun W, El Jabaly S. Effect of exposure to cement dust on pulmonary function among cement plants workers in the Middle Governorate, Gaza, Palestine. Public Health Res. 2015;5(5):129-34.

16. Spiro J. Occupational skin diseases. Princ Pract Ski Toxicol. 2008;27(4):259-77.

17. Normohammadi M, Kakooei H, Omidi L, Yari S, Alimi R. Risk assessment of exposure to silica dust in building demolition sites. Saf Health Work. 2016;7(3):251-5. https://doi.org/10.1016/j. shaw.2015.12.006 PMid:27630796

18. Mallongi A, Stang, Syamsuar M, Fajar MN, Pujiastuti RD, Rauf AU. Risks assessment of silica contamination on the communities living surround the cement industry, pangkep Indonesia. Indian J Public Health Med Res. 2019;10(10):1619. https://doi.org/10.5958/0976-5506.2019.03072.9

19. Omrani MA, Modarres A. Emulsified cold recycled mixtures using cement kiln dust and coal waste ash-mechanicalenvironmental impacts. J Clean Prod. 2018;199:101-11. https:// doi.org/10.1016/j.jclepro.2018.07.155

20. Thomas B, Kulichova D, Wolf R, Summer B, Mahler V, Thomas P. High frequency of contact allergy to implant and bone cement components, in particular gentamicin, in cemented arthroplasty with complications: Usefulness of late patch test reading. Contact Dermatitis. 2015;73(6):343-9. https://doi. org/10.1111/cod. 12465 PMid:26329644

21. Stern AH, Bagdon RE, Hazen RE, Marzulli FN. Risk assessment of the allergic dermatitis potential of environmental exposure to hexavalent chromium. J Toxicol Environ Health. 1993;40(4):61341. https://doi.org/10.1080/15287399309531822

\section{PMid:8277522}

22. Hedberg YS, Lidén $C$, Lindberg $M$. Chromium dermatitis in a metal worker due to leather gloves and alkaline coolant. Acta Derm Venereol. 2016;96(1):104-5. https://doi. org/10.2340/00015555-2160

PMid:26062867

23. Nijhawan RI, Molenda M, Zirwas MJ, Jacob SE. Systemic contact dermatitis. Dermatol Clin. 2009;27(3):355-64. https:// doi.org/10.1016/j.det.2009.05.005 PMid:19580929

24. Achmad RT, Auerkari El. Effects of chromium on human body. Annu Res Rev Biol. 2017;13(3):1-8.

25. Wong CC, Gamboni SE, Palmer AM, Nixon RL. Occupational allergic contact dermatitis to chromium from cement: Estimating the size of the problem in Australia. Australas J Dermatol. 2015;56(4):290-3. https://doi.org/10.1111/ajd.12238 PMid:25367657

26. Lison D. Cobalt. Handb Toxicol Met Fourth Ed. 2015;1:743-63.

27. HonKL, WangSS, HungEC, LamHS, LuiHH,ChowCM, etal.Serum levels of heavy metals in childhood eczema and skin diseases: Friends or foes. Pediatr Allergy Immunol. 2010;21(5):831-6. https://doi.org/10.1111/j.1399-3038.2010.01022.x

28. Darmono. Lingkungan Hidup dan Pencemaran: Hubungannya Dengan Toksikologi Senyawa Logam. Jakarta: Penerbiit Universitas Indonesia; 2010.

29. Wang BJ, De Wu J, Sheu SC, Shih TS, Chang HY, Guo YL, et al. Occupational hand dermatitis among cement workers in Taiwan. J Formos Med Assoc. 2011;110(12):775-9. https://doi. org/10.1016/j.jfma.2011.11.008 PMid:22248832

30. Schwensen JF, Menné T, Veien NK, Funding AT, Avnstorp C, Østerballe $\mathrm{M}$, et al. Occupational contact dermatitis in bluecollar workers: Results from a multicentre study from the Danish contact dermatitis group (2003-2012). Contact Dermatitis. 2014;71(6):348-55. https://doi.org/10.1111/cod.12277 PMid:25041423

31. García-Pérez J, López-Abente G, Castelló A, GonzálezSánchez M, Fernández-Navarro P. Cancer mortality in towns in the vicinity of installations for the production of cement, lime, plaster, and magnesium oxide. Chemosphere. 2015;128:10310. https://doi.org/10.1016/j.chemosphere.2015.01.020 PMid:25681568

32. Bermudez GM, Moreno M, Invernizzi R, Plá R, Pignata ML. Heavy metal pollution in topsoils near a cement plant: The role of organic matter and distance to the source to predict total and $\mathrm{HCl}$-extracted heavy metal concentrations. Chemosphere. 2010;78(4):375-81. https://doi.org/10.1016/j.chemosphere.2009.11.012 PMid:19962174

33. Elhosary N, Maklad A, Soliman E, El-Ashmawy N, Oreby M. Evaluation of oxidative stress and DNA damage in cement and tannery workers in Egypt. Inhal Toxicol. 2014;26(5):289-98. https://doi.org/10.3109/08958378.2014.885100 PMid:24617565

34. Khatami A, Nassiri-Kashani M, Gorouhi F, Babakoohi S, Kazerouni-Timsar A, Davari P, et al. Allergic contact dermatitis to metal allergens in Iran. Int J Dermatol. 2013;52(12):1513-8. https://doi.org/10.1111/j.1365-4632.2012.05623.x PMid:23488935

35. Rycroft RJ. Textbook of Contact Dermatitis. Berlin, Germany: Springer; 2001.

36. Thyssen JP, Ross-Hansen K, Menné T, Johansen JD. Patch test reactivity to metal allergens following regulatory interventions: $A$ 33-year retrospective study. Contact Dermatitis. 2010;63(2):1026. https://doi.org/10.1111/j.1600-0536.2010.01751.x PMid:20629675 